the more xenophobic elements of the British tabloid press, which have raised the prospect of the NHS being swamped by migrants from the acceding states while ignoring the probability that anyone moving to the United Kingdom is more likely to be providing rather than receiving health care. Any effects are likely to be gradual, but in the long term they could be substantial, albeit in ways that no one can now predict. Enlargement brings challenges, but also opportunities, and Europe's politicians and professional associations

1 European Community. Treaty establishing the European Community. Rome: European Community, 1957.

McKee M, MacLehose L, Nolte E, eds. Health policy and European Union enlargement. Buckingham: Open University Press, 2004

3 Osterberg E, Cilmore A. Z atonski W, Heloma A, Delchera E, McKee M. Osterberg E, Gilmore A, Zatonski W, Heloma A, Delchera E, Mckee Trade and public health. Alcohol and L, Nolte E, eds. Health Policy and European Union Enlargement. Buckingham: Open University Press, 2004 (in press).

4 McKee M, Mossialos E, Baeten R, eds. The impact of European Union law on health care systems. Brussels: Peter Lang, 2002. must continue to discuss how the European ideal can work to promote effective health policies that benefit all their citizens.

Martin McKee professor of European public health

(martin.mckee@lshtm.ac.uk)

Ellen Nolte lecturer in public health

European Observatory on Health Care Systems, London School of Hygiene and Tropical Medicine, London WC1E 7HT

Competing interests: None declared.

5 Belcher P, McKee M, Rose T. Is health in the European Convention? EuroHealth 2003;9:1-4.

Krosnar K. Could joining European Union club spell disaster for the new members? BMJ 2004:328:310.

7 Rechel B, McKee M. Healing the crisis. A prescription for public health action in south-eastern Europe. London: London School of Hygiene and Tropical Medicine, 2003

8 Coker RJ, Atun RA, McKee M. Health care system frailties and public health control of communicable disease on the European Union's new eastern border. Lancet 2004;363:1389-92.

\title{
Prevention of respiratory syncytial virus infection in infants
}

\section{Palivizumab is effective but too expensive, and vaccines are unavailable as yet}

B ronchiolitis due to respiratory syncytial virus is predictable, occurring during the dark winter in temperate climates and the rainy season in tropical countries. In the United Kingdom around 20\% of admissions for infections of the lower respiratory tract in children are due to respiratory syncytial virus. The annual incidence of hospital admissions related to respiratory syncytial virus is 28.3 per 1000 for infants, and 1.3 per 1000 for children aged $1-4$ years. ${ }^{1}$ Interestingly, the number of laboratory reports for respiratory syncytial virus shows a marked downward trend in England and Wales from 1990 to 2003 (figures 1 and 2). Although changes in clinical or laboratory practice may be an influence, data from primary care show a fall in acute respiratory infections over the same years. ${ }^{2}$ This is fortunate, as treating respiratory syncytial virus bronchiolitis remains a good example of therapeutic nihilism-nothing works except oxygen. Adrenaline, bronchodilators, steroids, and ribavirin all confer no real benefit. So if cure does not work, how are we doing with prevention?

Passive immunisation with the monoclonal antibody palivizumab is an option for high risk infants. The impact respiratory syncytial virus study, a double blind, placebo controlled, randomised study, showed that palivizumab was safe and decreased admissions related to respiratory syncytial virus in infants at high risk. ${ }^{3}$ The American Academy of Pediatrics revised its guidelines for passive immunisation against respiratory syncytial virus in $2003 .{ }^{4}$ Current recommendations are that palivizumab should be considered for premature infants born at less than 32-5 weeks' gestation or infants younger than 2 years, with chronic lung disease. In the United States around 100000 infants a year receive palivizumab.

The current NHS guidelines have been formulated by the joint committee on vaccination and immunisa-

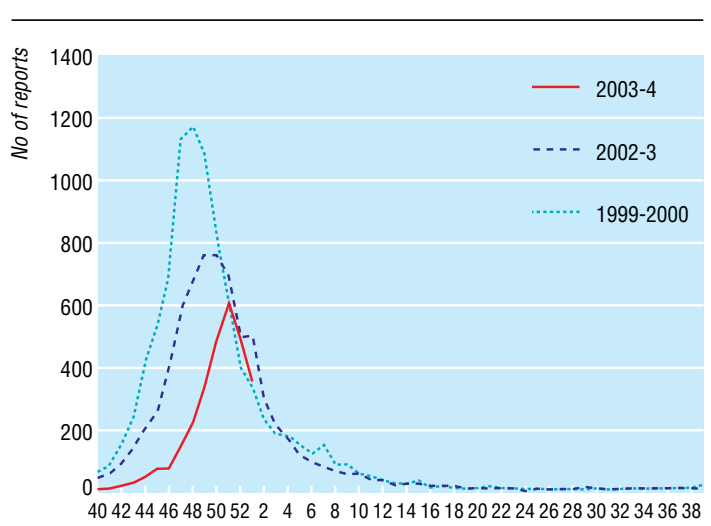

Weeks

Fig 1 Laboratory reports of respiratory syncytial virus received by the Communicable Disease Surveillance Centre and microbiology laboratories of the Health Protection Agency, by date of specimen in 2003-4 and recent years. Data for 2003-4 are provisional, and caution should be exercised in interpreting a trend for the most recent weeks

tion of the Department of Health. They note that palivizumab seems safe, well tolerated, and effective in reducing admissions to hospital, but it remains very expensive, at a cost of around £2500 for five doses over the season for respiratory syncytial virus. In the United Kingdom, studies on readmission rates with respiratory syncytial virus bronchiolitis show that palivizumab is cost effective only in infants born prematurely with chronic lung disease receiving oxygen at home. ${ }^{5}$ The cost-benefit ratio will shift against palivizumab even more if it becomes clear that admissions for bronchiolitis due to respiratory syncytial virus are falling in parallel with laboratory reports. Recently, a further study of palivizumab in infants with cardiac 


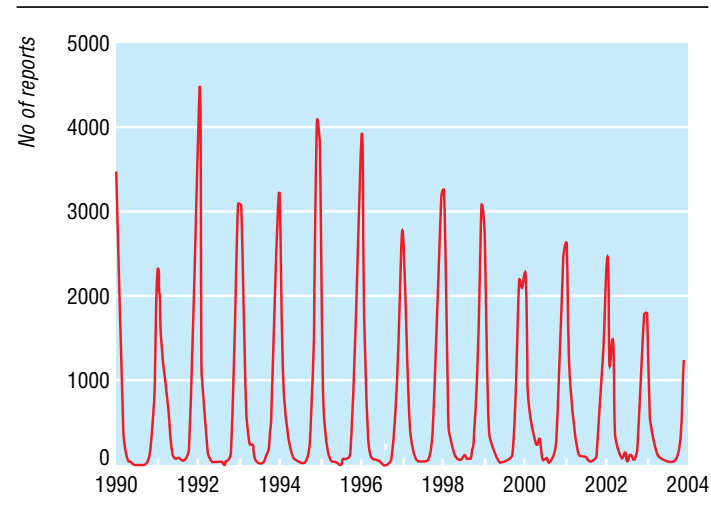

Year

Fig 2 Four weekly laboratory reports to the Communicable Disease Surveillance Centre of infections due to respiratory syncytial virus in England and Wales, by date of report, 1990-2003

disease has been completed, but data on admission, morbidity, and mortality and a detailed cost benefit analysis are required before it can be routinely recommended in this population. ${ }^{6}$ The reality is that except in the richest nations for very small subgroups of patients, palivizumab is too expensive to have any impact on overall respiratory syncytial virus admissions.

Developing an effective and safe respiratory syncytial virus vaccine remains a worldwide priority. ${ }^{7}$ Forty years have passed since the formalin inactivated respiratory syncytial virus vaccine was first used, with younger vaccinated children experiencing more severe respiratory syncytial virus disease and increased mortality. ${ }^{8}$ A successful respiratory syncytial virus vaccine needs to prevent severe lower respiratory tract disease, hospitalisation, and death. It must protect against both group A and B strains. It would need to be given after birth, to prevent primary infection with respiratory syncytial virus in infants. However, neonatal immunisation poses problems. Neonates and young infants may be unable to develop adequate antibody or $\mathrm{T}$ cell responses to vaccination. Also, maternally derived antibodies may interfere with the immunisation response.

Several vaccine strategies are currently under development. Firstly, maternal immunisation in the third trimester aims to boost serum neutralising antibodies passively transferred from mother to baby. This would protect young infants, who are most susceptible to serious respiratory syncytial virus disease. A second generation, purified $\mathrm{F}$ protein (PFP-2) subunit vaccine was safe with no enhanced disease in infants when 35 pregnant women were immunised in the third trimester. The women had a moderate immunogenic response. The infants had higher counts of immunoglobulin $\mathrm{G}$ antibodies against respiratory syncytial virus at birth, 2 months, and 6 months of age. ${ }^{9}$ This strategy would not protect infants born prematurely. Currently, purified F protein vaccines cannot be used in primary immunisation of infants because of limited immunogenicity.

Secondly, primary immunisation with live attenuated genetically modified viruses is another approach. A live attenuated vaccine should induce local and systemic immunity similar to wild type respiratory syncytial virus. It should be effective even in the presence of maternal antibodies. One interesting candidate vaccine contains live attenuated, cold passaged, temperature sensitive mutants of respiratory syncytial virus. It has been studied in healthy adults, respiratory syncytial virus seropositive children, and respiratory syncytial virus seronegative infants. ${ }^{10}$ These vaccines are not sufficiently attenuated or immunogenic to be of use in immunisation of infants as yet.

Thirdly, live recombinant virus vectors expressing respiratory syncytial virus proteins have been formulated in delivery systems based on vaccinia, adenovirus, and human rhinovirus. However, immunogenicity in animal models has been disappointing, and safety concerns remain. Dual effect vaccines are also being tested in which a parainfluenza vector carries respiratory syncytial virus subunits. ${ }^{11}$ Subunit vaccines have been shown to induce long lasting neutralising antibodies.

Despite an improved understanding of the inflammatory response seen in bronchiolitis due to respiratory syncytial virus ${ }^{12}$ with many promising vaccines and strategies, routine vaccination of infants for respiratory syncytial virus is unlikely in this decade.

Jenny Handforth specialist registrar

Mike Sharland consultant

(mike.sharland@stgeorges.nhs.uk)

Paediatric Infectious Diseases Unit, St George's Hospital, London SW17 0QT

\section{Jon S Friedland professor}

Department of Infectious Diseases, Imperial College School of Medicine, Hammersmith Hospital, London W12 0NN

Many thanks to Nichola Goddard, Communicable Disease Surveillance Centre, Health Protection Agency, Colindale, London, for providing the epidemiological data regarding respiratory syncytial virus.

Competing interests: None declared.

1 Müller-Pebody B, Edmunds WJ, Zambon MC, Gay NJ, Crowcroft N. Contribution of RSV to bronchiolitis and pneumonia-associated hospitalizations in English children, April 1995-March 1998. Epidemiol Infect 2002;129:99-106.

2 Fleming DM, Ross AM, Cross KW, Kendall H. The reducing influence of respiratory tract infection and its relation to antibiotic prescribing. $\mathrm{Br} \mathrm{J}$ Gen Pract 2003;53:778-83.

3 The Impact-RSV Study Group. Palivizumab, a humanized respiratory syncytial virus monoclonal antibody, reduces hospitalisation from respisyncytial virus monoclonal antibody, reduces hospitalisation from respi-
ratory syncytial virus infection in high risk infants. Pediatrics ratory syncytial
$1998 ; 102: 531-7$.

4 American Academy of Pediatrics. Respiratory syncytial virus. In: Pickering LK, ed. Red Book: 2003 Report of the committee on infectious diseases. 26th ed. Elk Grove Village, IL: American Academy of Pediatrics; 2003:523-8.

5 Joint Committee on Vaccination and Immunisation. Minutes of the meeting held on 1 November 2002. www.doh.gov.uk/jcvimins01nov02.htm (accessed 4 Mar 2004).

6 Feltes TF, Cabalka AK, Meissner HC, Piazza FM, Carlin DA, Top FH, et al for the Cardiac Synagis Study Group. Palivizumab reduces hospitalisation due to respiratory syncytial virus in young children with tion due to respiratory syncytial virus in young children with
haemodynamically significant congenital heart disease. J Pediatrics haemodynamically
2003; $143: 532-40$.

7 Crowe JE Jr. Current approaches to the development of vaccines against disease caused by respiratory syncytial virus (RSV) and parainfluenza virus (PIV): a meeting report of the WHO Programme for Vaccine Development. Vaccine 1995;13:415-21.

8 Kim HW, Canchola JG, Brandt CD, Pyles G, Chanock RM, Jensen K, et al. Respiratory syncytial virus disease in infants despite prior administration of antigenic inactivated vaccine. Am J Epidemiol 1969;89:422-34.

9 Munoz FM, Piedra PA, Glezen WP. Safety and immunogenicity of respiratory syncytial virus purified protein-2 vaccine in pregnant women. Vaccine 2003;21:3465-7

10 Piedra PA. Clinical experience with respiratory syncytial virus vaccines. Paediatr Infect Dis J 2003;22:S94-9.

11 Haller AA, Mitiku M, Macphail M. Bovine parainfluenza virus type 3 (PIV3) expressing the respiratory syncytial virus (RSV) attachment and fusion proteins protects hamsters from challenge with human PIV3 and fusion proteins protects hamsters from

12 Handforth J, Friedland JS, Sharland M. Basic epidemiology and immunopathology of RSV in children. Paediatr Respir Rev 2000;1:210-4. 